\title{
Synthesis of $\mathrm{Nb}_{2} \mathrm{O}_{5}$ thin films for electrochromic devices
}

\author{
A. PAWLICKA, M. ATIK, M. A. AEgERTER \\ Departamento de Física e Ciência dos Materiais, Instituto de Física de São Carlos, Universidade de São Paulo, \\ CP 369, CEP 13560-970 São Carlos (SP), Brazil
}

A large number of metal oxides such as $\mathrm{TiO}_{2}, \mathrm{CeO}_{2}$, $\mathrm{WO}_{3}, \mathrm{~V}_{2} \mathrm{O}_{5}$ and $\mathrm{Nb}_{2} \mathrm{O}_{5}$ have been investigated for their use in various solid state electrochemical devices, including batteries, and electrodes for photoelectrochemical and electrochromic devices $[1,2]$. One fundamental characteristic of these oxide films is their rapid and reversible coloration when small ions such as $\mathrm{H}^{+}$and $\mathrm{Li}^{+}$are inserted in the layer lattice, which typically changes their optical transmission from a quasi-transparent state ( $T \cong 85 \%$ ) to less than $T \cong 20 \%$ in the ultraviolet (UV), visible or near infrared (IR) range.

The electro-optical performance of electrochromic coatings is strongly dependent on their structural morphology. Outstanding performance has been obtained recently using materials constituted of aggregates of nano-sized particles with $\mathrm{CeO}_{2}-\mathrm{TiO}_{2}$ [3-6], $\mathrm{TiO}_{2}$ [7] and $\mathrm{Nb}_{2} \mathrm{O}_{5}[8,9]$. The sol-gel process is a particularly well-adapted method for achieving such morphology. Moreover, the dip coating technique, a common method of deposition in this field, allows the deposit of large-area coatings at a low cost and offers advantages in controlling the microstructure of the film.

Very few studies have been reported on the electrochromic properties of $\mathrm{Nb}_{2} \mathrm{O}_{5}$. Reichman and Bard [10] and Gomes et al. [11] found a blue coloration in opaque $\mathrm{Nb}_{2} \mathrm{O}_{5}$ grown thermally at $\sim 500{ }^{\circ} \mathrm{C}$ on niobium metallic disk. Alves [12] has confirmed the possibility of inserting $\mathrm{Li}^{+}$ions in a $\mathrm{Nb}_{2} \mathrm{O}_{5}$ ceramic prepared from a commercial powder sintered at $\sim 800^{\circ} \mathrm{C}$. The first attempt to fabricate sol-gel $\mathrm{Nb}_{2} \mathrm{O}_{5}$ for electrochemical purposes was reported by Lee and Crayston [13] using a sol made of a mixture of $\mathrm{NbCl}_{5}$ dissolved in ethanol. However, the $5-10 \mu \mathrm{m}$ thick film exhibited substantial cracking and peeling due to significant shrinkage during drying. More recently, using a sol prepared with niobium pentoxide, we have obtained homogeneous films without cracks and defects, which present good and promising electrochromic properties $[8,9]$.

In this letter we describe a novel and simpler synthesis of a sol-gel $\mathrm{Nb}_{2} \mathrm{O}_{5}$ precursor and report on the electrochromic properties of $\mathrm{Nb}_{2} \mathrm{O}_{5}$ coatings deposited by the dip-coating technique on ITOcoated glass.

The preparation of transparent and stable niobium solution was carried out using a sonocatalytic process [14-16], which gives coatings with good optical quality and interesting electrochromic properties. The starting solution to produce $\mathrm{Nb}_{2} \mathrm{O}_{5}$ films was prepared by dissolving $\mathrm{NbCl}_{5}$ powder $(0.2 \mathrm{M})$ in butanol $(0.28 \mathrm{M})$ and acetic acid $(0.05 \mathrm{M})$. The solution mixture was submitted for a few minutes of the action of ultrasonic irradiation (Sonicator W385 Heat System-Ultrasonic, Inc. at $20 \mathrm{kHz}$ ), resulting in a transparent and viscous solution stable for several months at room temperature. The main precursors are probably chloroalkoxides of the type $\mathrm{NbCl}_{5-x}(\mathrm{OBu})_{x}[17]$.

The coatings were deposited by dipping ITOcoated glass substrate (Asahi-Glass, $14 \Omega \square^{-1}$ ) previously cleaned and rinsed with doubly distilled water and ethanol and then dried at room temperature, into the solution in ambient atmosphere and withdrawing it at a rate of $12 \mathrm{~cm} \mathrm{~min}^{-1}$. The samples were subsequently dried in air at room temperature for $15 \mathrm{~min}$. The uniform gel films were then calcined at temperatures as high as $600^{\circ} \mathrm{C}$ using a heating rate of $10^{\circ} \mathrm{C} \mathrm{min}^{-1}$. The resulting coatings were then kept at the final temperature for $10 \mathrm{~min}$, and were found to be transparent and homogeneous with a thickness of about $100 \mathrm{~nm}$ after one dip. The morphology of the films visualized by atomic force microscopy (AFM) consisted of agglomerations of small particles of 30 $70 \mathrm{~nm}$ size.

$\mathrm{X}$-ray diffraction (XRD) measurements were performed on xerogels obtained from the same sols using a Rigaku model RU200B instrument with $\mathrm{Cu} K_{\alpha}$ radiation.

The electrochemical characteristics (voltammogram, chronoamperogram) were determined using a Solartron 1286 analyser and a conventional threeelectrode cell placed in a dry-box under dry $\mathrm{N}_{2}$. The counterelectrode was a platinum foil of $1 \mathrm{~cm}^{2}$ area and the quasi-reference electrode was a silver wire. The electrolyte was a $0.1 \mathrm{M}$ solution of $\mathrm{LiClO}_{4}$ dissolved in propylene carbonate (PC). The cell was previously purged with dry $\mathrm{N}_{2}$ gas.

The thickness of the films was measured with a Taylor-Hobson Talystep and the optical spectra in the UV-visible range were recorded in situ with a Cary 2315 spectrophotometer. The coated substrate was placed in a special electrochemical cell built with two flat fused quartz windows and the UV-visible spectra were measured before and after insertion of $\mathrm{Li}^{+}$cations at fixed potentials.

XRD measurements of xerogels obtained with the same sol heat treated at $600{ }^{\circ} \mathrm{C}$ for $10 \mathrm{~min}$ following the same protocol indicated that the material was crystalline, with TT structure [18], with $d=0.0393$, $0.0313,0.0244,0.0196, \quad 0.0175$ and $0.0159 \mathrm{~nm}$ (Fig. 1). 


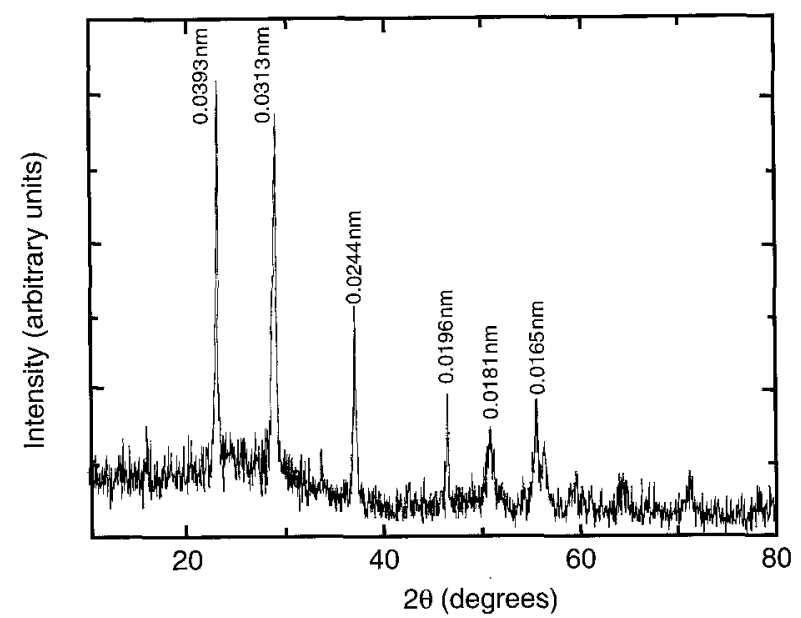

Figure 1 XRD pattern of $\mathrm{Nb}_{2} \mathrm{O}_{5}$ xerogel heat treated at $600{ }^{\circ} \mathrm{C}$ in air for $10 \mathrm{~min}$. showing the TT structure.

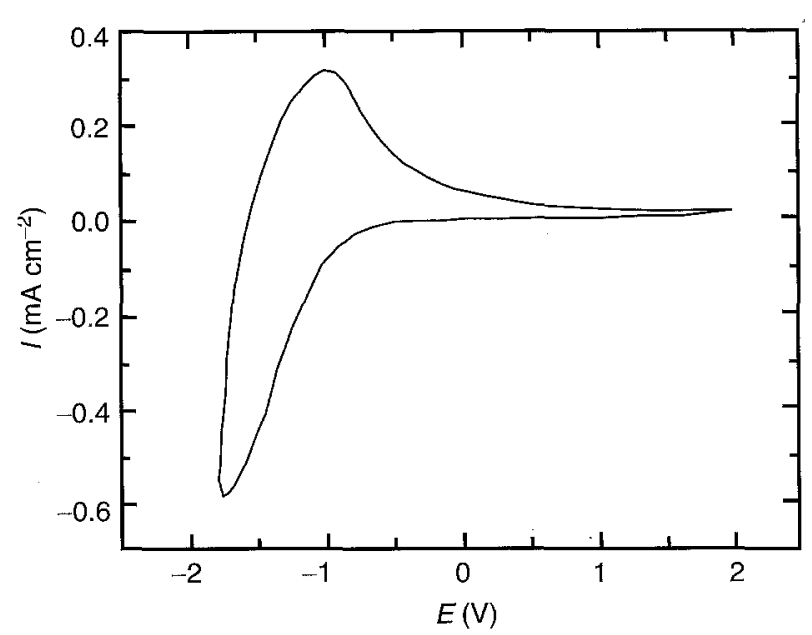

Figure 2 Typical cyclic voltammetry of a $\mathrm{Nb}_{2} \mathrm{O}_{5}$ film deposited on Asahi ITO-coated glass heat treated at $600{ }^{\circ} \mathrm{C}$ for $10 \mathrm{~min}$. Electrolyte (0.1 M) $\mathrm{LiClO}_{4} / \mathrm{PC}$, rate $50 \mathrm{mV} \mathrm{s}^{-1}$.

Fig. 2 shows a typical cyclic voltammogram registered with a one-layer (100 nm thick) $\mathrm{Nb}_{2} \mathrm{O}_{5}$ film heat treated at $600{ }^{\circ} \mathrm{C}$ for $10 \mathrm{~min}$. The cathodic peak, just barely observed, is associated with the $\mathrm{Li}^{+}$ insertion process. This insertion changes the colour of the film from transparent (slightly yellow) to dark blue at a potential of $-1.8 \mathrm{~V}$. The anodic peak observed at $-1.0 \mathrm{~V}$ is attributed to the extraction of $\mathrm{Li}^{+}$. The film again becomes transparent at $+2.0 \mathrm{~V}$. The measurements were done up to 100 cycles, and the insertion and extraction processes were found to be stable and fully reversible after the fourth cycle. The anodic and cathodic charge densities were measured from integration of the cyclic voltammograms. The exchanged charge was equal to $10 \mathrm{mC} \mathrm{cm}^{-2}( \pm 3 \%)$. The value of the exchanged charge increases with the thickness of the coatings and reaches, typically, $15 \mathrm{mC} \mathrm{cm}^{-2}$ for a three-dip film.

Fig. 3 shows the variations of the cell current as a function of time during repeated potential steps at intervals of $20 \mathrm{~s}$ between -1.8 and $2 \mathrm{~V}$. The cathodic current, which is responsible for the coloration and is

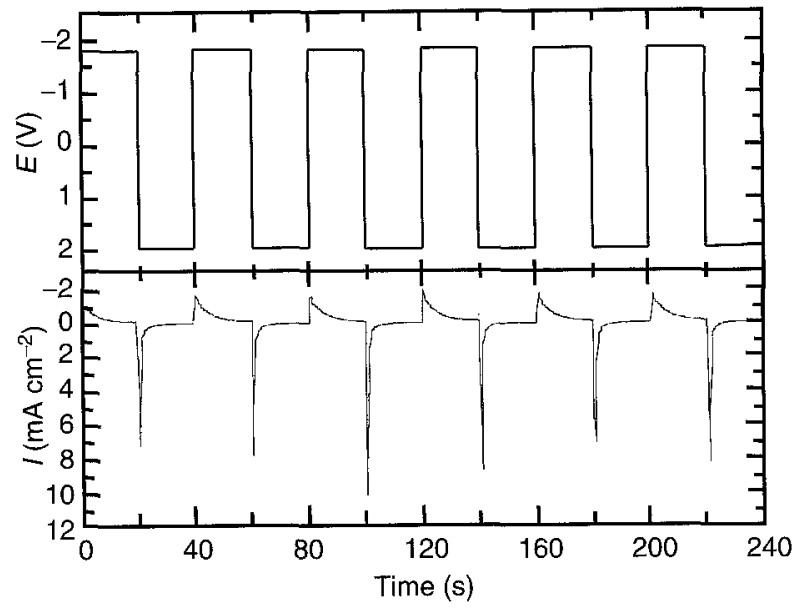

Figure 3 Chronoamperometry with potential steps at every $20 \mathrm{~s}$ between $-1.8 \mathrm{~V}$ and $2 \mathrm{~V}$.

seen after the potential step to $-1.8 \mathrm{~V}$, has relatively fast kinetics (a few seconds). The $\mathrm{Li}^{+}$extraction is, however, faster. The cyclic variation of the anodic peak intensity observed in Fig. 3 is instrumental.

Fig. 4 shows transmission spectra of $\mathrm{Nb}_{2} \mathrm{O}_{5}$ film deposited onto ITO electrode in the reduced and oxidized state for one- and two-dip layers measured in situ at a fixed potential of $+2.0 \mathrm{~V}$ (bleached state) and $-1.8 \mathrm{~V}$ (coloured state). The insertion of $\mathrm{Li}^{+}$ changes the transmissivity in the visible-near IR range from about $80 \%$ to about $40 \%$ for a $100 \mathrm{~nm}$ thick $\mathrm{Nb}_{2} \mathrm{O}_{5}$ layer and to less than $20 \%$ for a $200 \mathrm{~nm}$ thick (two-dip) coating.

All of these results are quite similar to those already obtained using sol-gel $\mathrm{Nb}_{2} \mathrm{O}_{5}$ coatings made with sols prepared from classic $\mathrm{Nb}$ alkoxides without sonocatalytic irradiation $[8,9]$. However, this new route is much easier and quicker to prepare the sols.

In conclusion, we have shown that films of $\mathrm{Nb}_{2} \mathrm{O}_{5}$ prepared by the sonocatalytic method are promising candidates for electrochromic devices using either protonic or lithium electrolytes. Coatings calcinated at $600{ }^{\circ} \mathrm{C}$ in air have a crystalline TT structure and

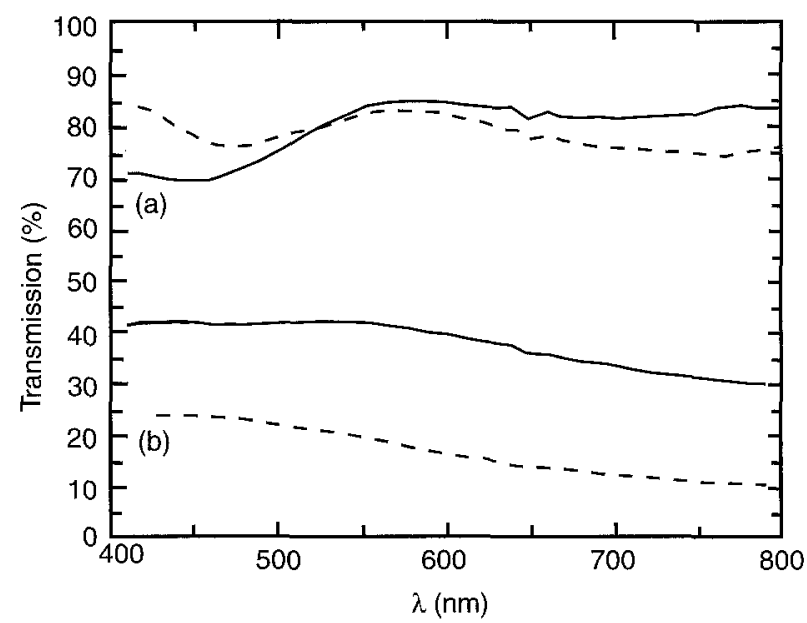

Figure 4 UV-visible spectral variation observed during electrochromic switching of (- - ) one- and (- - ) two-dip $\mathrm{Nb}_{2} \mathrm{O}_{5}$ films (a) before (bleached) and (b) after (coloured) polarization at $-1.8 \mathrm{~V}$. 
present a good, reversible and fast insertion extraction of $\mathrm{Li}^{+}$ions. The charge density inserted in one layer is $10 \mathrm{mC} \mathrm{cm}^{-2}$.

\section{Acknowledgement}

The authors acknowledge financial support from CNPq.

\section{References}

1. M. A. AEGERTER, in "Structure and bonding", edited by R. Reisfeld and C. K. Jorgensen (Springer-Verlag, Berlin, 1995).

2. C. M. LAMPERT and C. G. GRANQUIST, (editors), "Large-area chromogenics: materials and devices for transmittance control", Vol. IS4 (SPIE, Bellingham, USA, 1990).

3. P. BAUDRY, A. C. M. RODRIGUES, M. A. AEGERTER and L. O. S. BULHÓEE, J. Non-Cryst. Solids 121 (1990) 319.

4. J. C. L. TONAZZI, B. VAlla, M. A. MACÊDO, P. BAUDRY and $M$. A. AEGERTER, in "Proceedings on sol-gel optics", Vol. 1328, edited by J. D. Mackenzie (SPIE, Bellingham, USA, 1990) p. 375.

5. M. A. MACÊDO, L. H. DALL'ANTONIA and M. A. AEGERTER, in "Proceedings on sol-gel optics II", Vol. 1758, edited by J. D. Mackenzie (SPIE, Bellingham, USA, 1992) p. 320.

6. D. KÉOMANY, J.-P. PETIT, and D. DEROO, in "Proceedings on optical material technology for energy efficiency and solar energy conversion XIII', Vol. 2255, edited by V. Wittwer, C. G. Granquist and C. M. Lampert (SPIE, Bellingham, USA, 1994) p. 363
7. A. HAGFELDT, N. VLACHOPOULOS and $M$ GRÄTZEL, J. Electrochem. Soc. 141 (1994) L82.

8. C. O. AVELlaneda, M. A. MACÊDO, A. O. FLORENTINO and $M$. A. AEGERTER, in "Proceedings on optical materials technology for energy efficiency and solar energy conversion XIII", Vol. 2255, edited by V. Wittwer, C. G. Granquist and C. M. Lampert (SPIE, Bellingham, USA, 1994) p. 38.

9. C. O. AVEllaneda, M. A. MACÊDO, A. O. FloRENTINO, D. A. BARROS FILHO and M. A. AEGER TER, in "Proceedings on sol-gel optics III', Vol. 2288, edited by J. D. Mackenzie (SPIE, Bellingham, USA, 1994) p. 422 .

10. B. REICHMAN and A. J. BARD, J. Electrochem. Soc. 127 (1980) 241.

11. M. A. B. GOMES, L. O. S. BULHÖES, S. C. CASTRO and A. J. DAMI ̃̃O, ibid. 137 (1990) 3067

12. M. C. ALVES, MSc thesis, Federal University of São Carlos, São Carlos, Brazil (1989).

13. G. R. LEE and J. A. CRAYSTON, J. Mater. Chem. 1 (1991) 381.

14. M. ATIK and M. A. AEGERTER, J. Non-Cryst. Solids 147/148 (1992) 813

15. P. DE LIMA NETO, M. ATIK, L. A. AVACA and M. A. AEGERTER, J. Sol-Gel Sci. Technol. 1 (1994) 177.

16. M. ATIK and J. ZARZYCKI, J. Mater. Sci. Lett. 13 (1994) 1301.

17. G. R. LEE and J. A. CRAySTON, J. Chem. Soc. Dalton Trans. No. 11, November (1991) 3073.

18. E. I. KO and J. G. WEISMANN, Catal. Today 8 (1990) 27. 